\title{
THE AESTHETIC FEATURES OF KOREAN ALPHABETIC SYSTEM-HANGUL
}

\author{
M. Ertan Gökmen
}

\begin{abstract}
The Korean alphabet, Hangul, is the unique alphabet which has a definite production process. All of the letters of Hangul can be defined in terms of production according to their aesthetic features. The main consonants were produced due to the articulation places in the mouth and the others were produced adding some other additional strokes on them. Vowels are based on the cosmic representation which consist of three original letters where the others are produced upon these three letters.
\end{abstract}

Key Words: Hangul, Korean Alphabet, Aesthetics, Consonant, Vowel

\section{KORE ALFABESİ-HANGUL'UN ESTETIKK ÖZELLİKLERİ}

\section{Özet}

Hangul olarak bilinen Kore Alfabesi oluşturulma süreçleri bakımından özel bir alfabedir. Hangul içerisinde yer alan bütün harflerin estetik özellikleri bakımından oluşumları açıklanabilmektedir. Temel ünsüzler temsil ettikleri seslerin ă̆ızda söyleyiş yerlerine göre yapılmış, diğer ünsüzler de bu temel ünsüzlere eklenen bazı çizgilerle şekillendirilmiştir. Ünlüler ise evrensel imgelemeden meydana gelen üç temel harften oluşturulmuştur. Diğer ünlüler de bu üç temel harften kaynaklanmaktadır.

Anahtar Sözcükler: Hangul, Kore Alfabesi, Estetik, Ünsüz, Ünlü 


\section{Introduction}

Hangul is the name of the unique alphabet which is being used by Koreans in the Korean Peninsula. The Korean alphabet is used by only Koreans which can be considered as unlike any other alphabet in the world.

For all Koreans, not only in the South but also in the North, Hangul is one of the powerful cultural icons. It's the symbol of nation and national cultural heritage. That the writing system is completely and uniquely Korean is enough to swell the pride of nation. Also that it's also one of the most remarkable writing system ever invented makes it fully deserving of attention in the wider world (Lee\&Ramsey, 2000).

\section{Invention of the Hangul - Brief History}

Before inventing the Hangul, in the peninsula the Chinese characters were being used as it had been imported from China by the early centuries of A.D.. By using the literary Chinese characters Korea became a literate society (Lee \& Ramsey, 2000).

As being of foreign origin, the Chinese characters, which were used until $15^{\text {th }}$ century, were not capable of expressing all of the sounds in Korean phonetic system. Therefore, King Sejong (1418-1450 AD), the $4^{\text {th }}$ ruler of the Choson Dynasty, established an institution called Chiphyonjon in the palace and ordered the scholars to invent a new writing system in 1443 . Though the king is generally referred to as "inventor" Hangul was in reality the result of years of research by the king and a team of scholars established by himself. Using Sejong's name as sole inventor gave gravitas and authority to the invention (Gaur, 2000). After completing the 4 year researches and working on it, scholars have presented the new Korean writing symbols to the king and then King Sejong has proclaimed this alphabet to the Korean people as Hunmin chong-um (correct sounds for instructing the people). The most important motivation on inventing a new alphabet was not having a unique writing system at that time and was also being used the Chinese characters known as Hancha among a restricted population. However the usage of the pictographic Sino-Korean Hanchas were being caused a lot of difficulties on expressing themselves in written Korean. King Sejong was very regretful on being not able to write and read by the ordinary Koreans but except some intellectuals and high society called Yangbans. So, that situation has motivated him inventing a new, widely usable letters to use by all population. However, by the influence of the widely accepted traditions in the peninsula and by the prevailed yangbans, scholars and the 
high society continued to use the Chinese characters as the literary script until 1945. What was the most pathetic situation for the Hangul during the half milenium is that it was called a writing system for women and children to insult not only the letters but also people who were trying to use it. So we can easily assume that Hangul was thought fit mainly for the consumption of women and people of low social rank.

On the other hand, for some scholars Hangul is not that enough to emphasize all of the sounds of the Korean sound system and because of this reason Chinese writing system is still somehow prestigious in Korea like in Japan. These considerable resistant scholars were the aristocratic elites in Korean society who perceived it as a threat to their own social, aristocratic, or some governmental position. In consequence, the new script, though ideally suited for Koreans, did not replace Chinese but was used side by side with the Chinese characters as an aid for pronunciation, for grammatical word or to clarify ambiguities (Gaur, 2000). However, North Korea has totally prohibited the usage of Chinese characters either in daily life or scientific environment and promoted Hangul in all written materials.

Moreover Hangul is accepted to be one of the most scientific alphabet in the world among the alphabets that are being used in present. Also, it was listed on the Memory of the World International Register of UNESCO on October 1997.

\section{The Letters of the Hangul}

Hangul consists of forty letters and is capable of expressing any sound in Korean. Twenty-one of these represent vowels (including thirteen diphtongs) and nineteen represents consonants. Twenty-four are basics while the others are the compounds of the basics. Mainly consonants were made by the pictographic ways while vowels were made by the symbolic and cosmic ways (Hon, 2003).

\section{Vowels}

The vowels of Hangul are based on the three letters originated from the cosmic represantation which all of the vowels are created by combining these letters. These are:

the dot (.) - represents the heaven

the horizontal line $(-)$ - represents the earth

the vertical line $(\mid)$-represents the man 
According to the above mentioned creation process, all of the vowels including diphtongs and triphtongs are as follows:

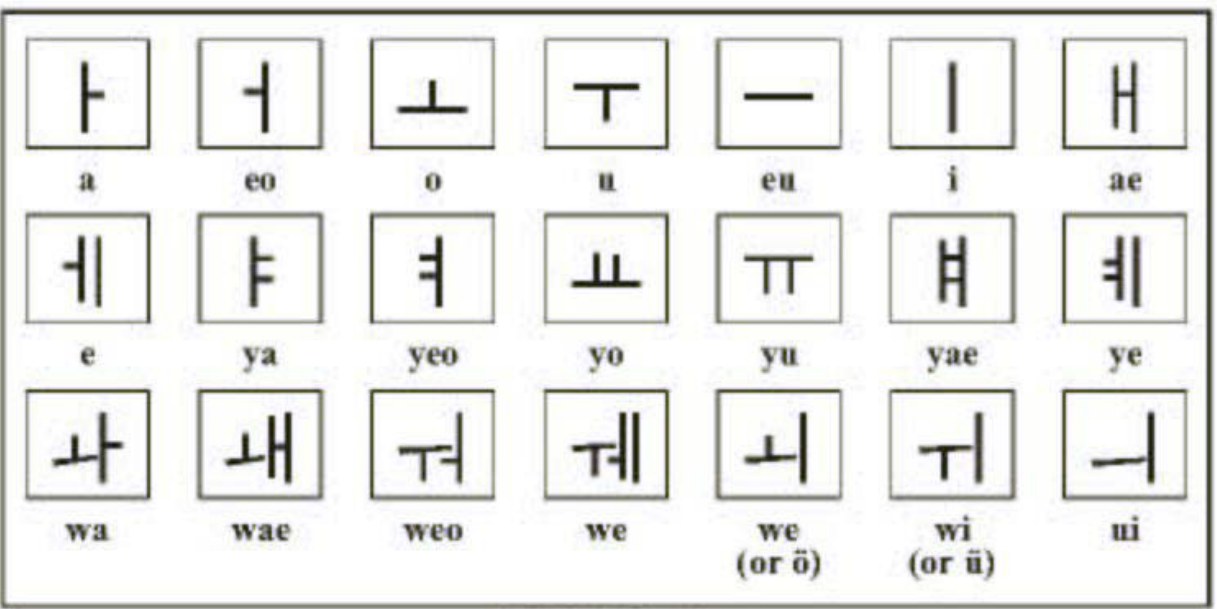

$\underline{\text { Table-1 Vowels }}$

All symbols of Hangul are written from top to bottom and from left to right. The order of the strokes is as illustrated below. Strokes are never interrupted, not even when they change the direction halfway.

\section{Consonants}

Consonants are based upon the position and shape of the vocal organs like mouth, tongue and lip when they are pronounced. In other words, the individual consonants are graphic representations of the way the organs of speech are used to articulate them. The five letters of the consonants are the basic letters and the other consonants are based on these five letters by adding and combining some diacritics on them. The basic consonants' sound properties and also their representations are as follows:

\begin{tabular}{|c|c|c|}
\hline Letters & Sound Properties & Representation \\
\hline 7 & Velar & Palate \\
\hline L & Alveolar & Palate \\
\hline 口 & Bilabial & Mounth \\
\hline 人 & Dental & Teeth \\
\hline O & Glottal & Gullet \\
\hline
\end{tabular}

Table-2 Basic Consonants 


\begin{tabular}{|l|l|}
\hline Petter & $\begin{array}{l}\text { Pronounciation } \\
\text { molar teeth and sticks near } \\
\text { the uvula. }\end{array}$ \\
\hline $\begin{array}{l}\text { the front of the tongue curves } \\
\text { and the tip of the tongue } \\
\text { sticks to the upper gums. }\end{array}$ & $\begin{array}{l}\text { upper and lower lips are } \\
\text { joined. }\end{array}$ \\
\hline $\begin{array}{l}\text { letter that is created by } \\
\text { stimulating the uvula, the } \\
\text { throat assumes a round shape, } \\
\text { hence the form of the } \\
\text { consonant. }\end{array}$ & $\begin{array}{l}\text { the tip of the tongue and the } \\
\text { upper teeth are brought close } \\
\text { together, and sound is creat- } \\
\text { narrowed by blowing through the }\end{array}$ \\
\hline & \begin{tabular}{l} 
nassage. \\
\hline
\end{tabular}
\end{tabular}

Table-3 Pronounciation and Articulation Places of the Basic Letters (1) 


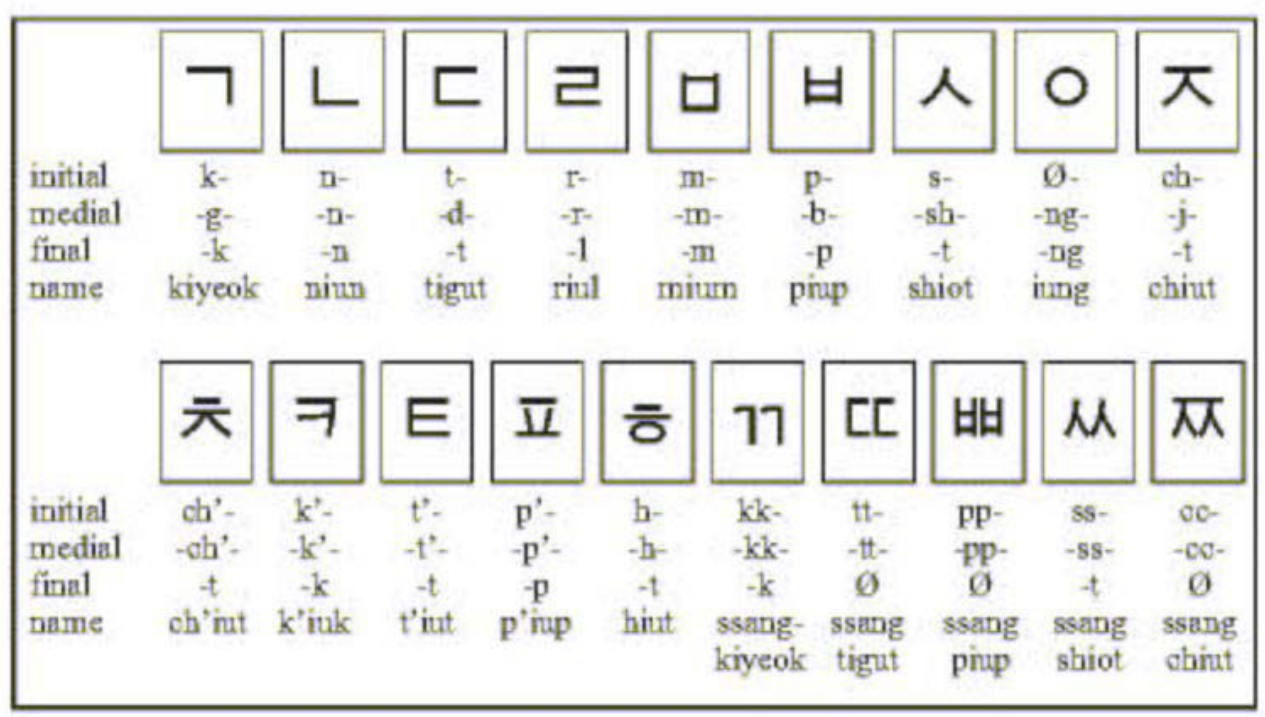

Table-4 Place of Articulation of the Consonants

\section{Structural Process of the Consonants Based on the Basic Letters}

These consonants are produced by copying of the shapes of the speech organs as it was mentioned above. The other consonants which were produced by adding some other elements on the basics are as follows:
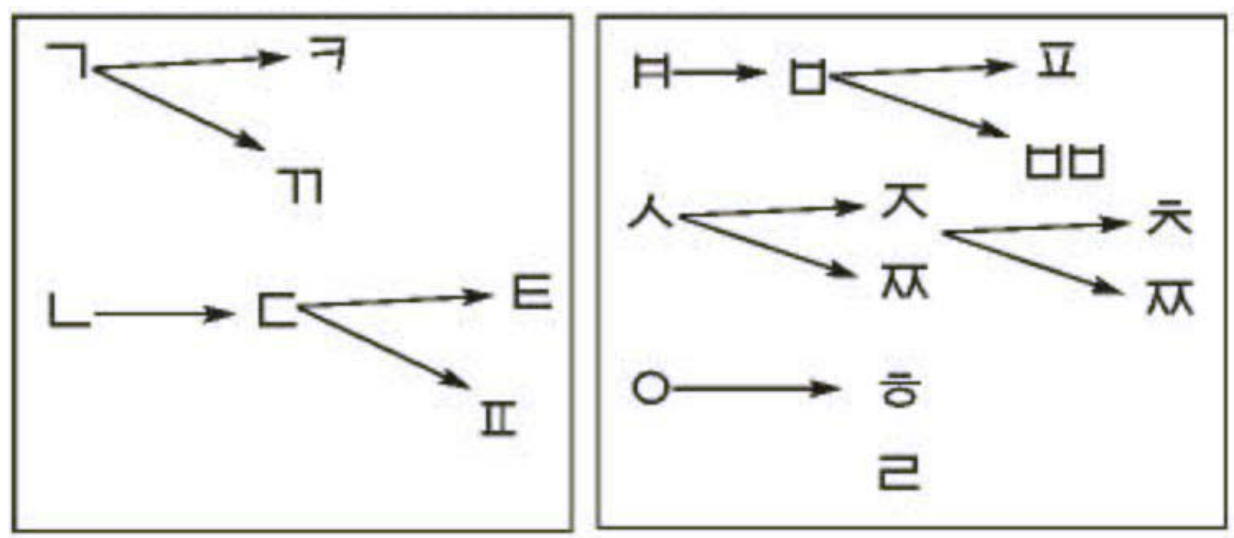

28 letters of Hangul is not made seperately but made of basic letters first and then followed by the rest. Moreover, the letters represent themselves as the characteristics of the sound value. For example ' $L$ ' (n) is modeled after the shape of the tongue touching the gums and ' $C$ ' (d) added a stroke on the ' $L$ ' representing the sound in the same position of the mouth. 


\section{Syllables}

Korean syllables are divided into three parts:

Ch'osong: initial consonant-syllable onset

Chungsong: medial/peakvowel/diphtong/tripthong- syllable nucleus

Chongsong: final consonant-syllable coda

\section{The Philosopical Features of the Hangul}

The main philosophy of the Hunmincheongum is the science of divination Yeok-hak in which the main principle is based on the Yin and Yang principle. Therefore, we can say that Hangul is a formative and visual result of accomplishment of the Yin and Yang principle due to the Great Absolute. In Hunmincheongum, according to the Yeok, the first sound is heaven and the final sound is earth. Man stays in between the heaven and earth. The aim of this is to keep the balance with harmony and going up to the idea of unity. So it is claimed that Hangul reflects everything in the world including the voice of human beings (Ahn, 2003).

According to the Yin-Yang principle, the forms of the letters in the Hangul followed by the Yin and Yang principle are vertically and horizontally symmetrical.

\section{Result}

Hangul has sound values and it can express all sounds of nature and humans. Besides it's so scientific, systematic and easy to learn that we can use it without any difficulty both in scientific and public use in the society. Therefore, it's

recognized as one of the most scientific and creative alphabet in the world.

After Hangul became the official letters in Korea, the lack of the education, the class discrimination, the problem of uneducated population began to reduce. If we consider the literacy rate of the 2006 we can see that it has reached to the $99 \%$ so that this rate shows how Hangul supports the Korean society to become a literate society.

As we have mentioned above, the Hangul has Great Absolute property based on the Yin and Yang Principle as we can see in all other features of Korean culture. The Great Absolute is not only found in the letters but also in the National Flag which is called as Taeguk Flag, in the social life, in the interpersonal relations, in the spoken language like the concrete honorific expression and so forth. Summing up of those Great Absolute values as a whole in Korean society, we can argue that Korean culture presents the harmony which is one of the proofs of the amazing development in the Korea. 


\section{References}

Ahn, Sang-Soo, 2003, "Hangul Design and Oullim, The Great Harmony": Osaka University The $21^{\text {st }}$ Century COE Program Interface Humanities Research Activities $2002 * 2003$, Osaka.

Gaur, Albertine, 2000, Literacy and the Politics of Writing, Intellect Books, Bristol, GBR http://site.ebrary.com/lib/ankarauniv/Doc?id=10035642ppg=112

Hannas, Williams, 1997, Asia’s Orthographic Dilemma, University of Hawaii Press, Honolulu, HI, USA.

http://site.ebrary.com/lib/ankarauniv/Doc?id=10015621\&ppg=60

Hon, Yun-Pyo, 2003, "Formative Principles and Change of Application Methods of Hangul": The $21^{\text {st }}$ Century COE Program Interface Humanities Research Activities 2002*2003, Osaka.

Lee, Iksop\&Ramsey S.Robert, 2000, The Korean Language, State University of New York Press, Albany, USA.

Lee, Iksop\&Lee, Sang-Oak, 1997, Hanguk-ui eoneo, Shingoo Munhwasa Press, Seoul.

Verhoeven, Ludo (Editor), 2002, Precursors of Functional Literacy, John Benjamin Publishing Company, Philadelphia, PA, USA.

http://site.ebrary.com/lib/ankarauniv/Doc?id=10046266\&ppg=148

1. http://www.wright-house.com/korean/korean-graphic/linguistic/consonants-5-groupdiagram.gif 